\title{
PELATIHAN MERANCANG MEDIA AUDIO VISUAL BERBASIS PERFORMANCE ASSESMENT DALAM PELAKSANAAN LAYANAN INFORMASI BIMBINGAN KONSEING BAGI MAHASISWA JURUSAN BK FIP UNDIKSHA
}

\author{
Putu Ari Dharmayanti 1,*, Ketut Gading2 ${ }^{2}$, Luh Putu Sri Lestari ${ }^{3}$ \\ 1 Jurusan Bimbingan Konseling. Universitas Pendidikan Ganesha, Indonesia \\ 2 Jurusan Bimbingan Konseling. Universitas Pendidikan Ganesha, Indonesia \\ 3 Jurusan Bimbingan Konseling. Universitas Pendidikan Ganesha, Indonesia
}

\begin{abstract}
Abstrak
Tujuan P2M ini adalah Meningkatkan pemhaman guru BK SMA/SMK di Kota singaraja mengenai langkah-langkah dalam merancang media audio visual berbasis performance assesment dalam pelaksanaan layanan informasi BK Serta Meningkatkan kemampuan guru BK SMA/SMK merancang media audio visual berbasis performance assesment dalam pelaksanaan layanan informasi BK. Metode yang digunakan untuk mencapai tujuan yang telah dirumuskan dalam P2M ini adalah metode ceramah, diskusi dan juga pelatihan (merancang meda audio visual dan refleksi) yang dilaksanakan dalam bentuk seminar dan workshop. Keberhasilan kegiatan pelatihan ini akan dievaluasi melalui: 1) Evaluasi proses: dilihat dari aktifitas peserta mengikuti kegiatan pelatihan, hal ini ditunjukan dengan partisipasi pesrta dalam diskusi (mengajukan atau menjawab pertanyaan), kehadiran peserta dalam kegiatan, kerjasama peserta dalam kegiatan (mau melaksanakan instruksi yang diberikan oleh narasumber maupun ketua pelaksana). Evaluasi proses dilaksanakan selama kegiatan P2M dilaksanakan. 2) Evaluasi hasil/produk: dilakukan terhadap kemampuan peserta dalam merancang media audio visual dalam kegiatan layanan informasi BK. dan juga penilaian terhadap produk media yang dihasilkan maka dapat disimpulkan bahwa pelaksanaan P2M berhasil, karena rancangan yang dibuat sesuai dengan indicator dan tagihan yang diminta oleh pelaksana dan juga peserta sudah menunjukan keseriusannya dalam membuat rancangan tersebut.
\end{abstract}

Konselor dalam sistem pendidikan nasional dinyatakan sebagai salah satu kualifikasi pendidik, sejajar dengan kualifikasi guru, dosen, pamong belajar, tutor, widyaiswara, fasilitator, dan instruktur (UU No. 20 Tahun 2003 Pasal 1 Ayat 6). Kesejajaran posisi ini tidaklah berarti bahwa semua tenaga pendidik itu tanpa keunikan konteks tugas dan ekspektasi kinerja. Demikian juga konselor memiliki keunikan konteks tugas dan ekspektasi kinerja yang tidak persis sama dengan guru. Hal ini mengandung implikasi bahwa untuk masing-masing kualifikasi pendidik, termasuk konselor, memerlukan upaya pembentukan kualifikasi akademik dan kompetensi berdasar kepada konteks tugas dan ekspektasi kinerja masingmasing. Peraturan Menteri Pendidikan Nasional No 27 Th. 2008 tentang Standar Kualifikasi Akademik dan Kompetensi Konselor (Pasal 1) secara tegas menyebutkan bahwa untuk dapat diangkat sebagai konselor, seorang wajib memenuhi standar kualifikasi akademik dan kompetensi konselor yang berlaku secara nasional. Selanjutnya penyelenggara pendidikan yang satuan pendidikannya memperkerjakan konselor wajib menerapkan standar kualifikasi akademik dan kompetensi konselor. Penguasaan keterampilan konseling bagi konselor memungkinkan terselenggaranya pelayanan konseling yang professional dan memandirikan serta menghindarkan tercederainya praktik profesi konselor.

Salah satu kompetensi dasar yang harus dimiliki konselor adalah kemampuan menggunakan dan mengoperasionalkan media bimbingan dan konseling. Kemampuan ini diperlukan karena dalam kegiatannya seorang konselor hendaknya mampu merancang, menggunakan, dan mengevaluasi efektivitas penggunaan media dalam pelayanan bimbingan dan konseling. Melalui perencanaan yang baik 
akan memperoleh kejelasan arah penggunaan media bimbingan dan konseling dan memudahkan untuk mengontrol kegiatan yang dilaksanakan. Lebih lanjut, Briggs (dalam Sadiman, dkk, 2002) menyatakan bahwa media adalah segala alat fisik yang dapat menyajikan pesan serta merangsang siswa untuk belajar dan atau menerima layanan bimbingan dan 4 konseling.

Definisi tersebut mengarahkan kita untuk menarik suatu simpulan bahwa media adalah segala jenis (benda) perantara yang dapat menyalurkan informasi dari sumber informasi kepada orang yang membutuhkan informasi Lebih lanjut, dalam kegiatan layanan bimbingan dan konseling dikenal pula istilah media bimbingan dan konseling. Suyitno (1997) menyatakan bahwa media bimbingan dan konseling adalah suatu peralatan baik berupa perangkat lunak maupun perangkat keras yang berfungsi sebagai alat bantu bimbingan dan alat bantu mengajar. Sebagai alat bantu dalam kegiatan layanan bimbingan dan konseling, maka media bimbingan ini akan disesuaikan dengan karakteristik masingmasing materi bimbingan dan konseling yang akan disajikan juga memperhatikan karakteristik siswa.

Untuk melihat aktifitas guru BK SMA/SMK dalam merancang media audio visual BK maka pemantauan ini meliputi proses maupun hasil, maka diperlukan asesmen yang digunakan, dimana dalam asesmen yang dilakukan tersebut harus terdapat suatu umpan balik yang efektif, baik efektif dalam arti mengoptimalkan hasil maupun efektif dalam arti membangun tanggungjawab belajar pada diri mahasiswa.oleh karena itu pelatihan ini menggunakan Performance assessment adalah penilaian berdasarkan hasil pengamatan penilai terhadap aktivitas siswa sebagaimana yang terjadi. Penilaian dilakukan terhadap unjuk kerja, tingkah laku, atau interaksi mahasiswa. Performance assessment digunakan untuk menilai kemampuan mahasiswa melalui penugasan. Penugasan tersebut dirancang khusus untuk menghasilkan respon (lisan atau tulis), menghasilkan karya (produk), atau menunjukkan penerapan pengetahuan.

Tugas yang diberikan kepada mahasiswa harus sesuai dengan kompetensi yang ingin dicapai dan bermakna bagi mereka (Setyono, 2005). Sedangkan menurut Majid (2006) performance assessment merupakan penilaian dengan berbagai macam tugas dan situasi di mana peserta diminta untuk mendemonstrasikan pemahaman dan mengaplikasikan pengetahuan yang mendalam, serta keterampilan di dalam berbagai macam konteks. Jadi dapat dikatakan bahwa performance assessment adalah suatu penilaian yang meminta peserta untuk mendemostrasikan dan mengaplikasikan pengetahuan ke dalam berbagai macam konteks sesuai dengan kriteria-kriteria yang diinginkan. Berdasarkan kedua pendapat tersebut dapat disimpulkan bahwa performance assessment dalam penelitian ini adalah suatu bentuk penilaian untuk mendemostrasikan atau mengaplikasikan pengetahuan yang telah diperoleh oleh mahasiswa dan menggambarkan suatu kemampuan mahasiswa melalui suatu proses, kegiatan, atau unjuk kerja. Karakteristik performance assesment menurut Norman (dalam Siti Mahmudah, 2000) adalah (1) tugas-tugas yang diberikan lebih realistis atau nyata; (2) tugas-tugas yang diberikan lebih kompleks sehingga mendorong siswa untuk berpikir dan ada kemungkinan mempunyai solusi yang banyak;(3) waktu yang diberikan untuk asesmen lebih banyak; (4) dalam penilaiannya lebih banyak menggunakan pertimbangan. Hal senada juga diungkapkan oleh Setyono (2005) bahwa performance assesment digunakan untuk menilai kemampuan siswa melalui penugasan yang berupa aspek pembelajaran kinerja dan produk, sedangkan Hutabarat (2004) berpendapat bahwa performance assesment lebih tepat untuk menilai kemampuan siswa dalam menyajikan lisan, pemecahan masalah dalam suatu kelompok, partisipasi siswa dalam suatu kegiatan pembelajaran, kemampuan siswa dalam menggunakan peralatan laboratorium serta kemampuan siswa mengoperasikan suatu alat.

Adapun langkah-langkah yang perlu dilakukan dalam membuat dan menggunakan performance assessment adalah 1) identifikasi semua langkah penting atau aspek yang diperlukan atau yang akan mempengaruhi hasil akhir; 2) menuliskan kemampuan-kemampuan khusus yang diperlukan untuk menyelesaikan tugas; 3) mengusahakan kemampuan yang akan diukur tidak terlalu banyak sehingga semua dapat diamati; 4) mengurutkan kemampuan yang akan diukur berdasarkan urutan yang akan diamati; 5) bila menggunakan skala rentang, perlu menyediakan kriteria untuk setiap pilihan (Hutabarat, 2004) sedangkan Majid (2006) mengemukakan langkah-langkah membuat dan menggunakan performance assessment adalah 1) melakukan identifikasi terhadap langkah-langkah penting yang diperlukan atau yang akan mempengaruhi hasil akhir (output yang terbaik); 2) menuliskan perilaku kemampuan spesifik yang penting dan diperlukan untuk menyelesaikan dan menghasilkan output yang terbaik; 3) membuat dan menggunakan kriteria-kriteria kemampuan yang akan diukur, jengan terlalu banyak sehingga semua kriteria- kriteria tersebut dapat diobservasi selama siswa melaksanakaan tugas; 4) mengurutkan kriteria-kriteria kemampuan yang akan diukur berdasarkan urutan yang dapat diamati; 5) kalau ada periksa kembali dan bandingkan dengan kriteria-kriteria kemampuan yang dibuat sebelumnya oleh orang lain.

Untuk menentukan validitas dan reliabilitas dalam performance assessment ada beberapa langkah yang harus diperhatikan yaitu 1) menentukan tujuan penilaian yang jelas sebelum memulai; 2) 
mengajar siswa dengan kinerja yang diinginkan, dan 3) memberitahukan kepada siswa tentang kriteriakriteria kinerja yang akan dipertimbangkan (Airasian, 1991). Salah satu kompetensi dasar yang harus dimiliki guru BK adalah kemampuan merancang media BK. Kemampuan ini diperlukan karena Melalui perencanaan yang baik akan memperoleh kejelasan arah penggunaan media bimbingan dan konseling dan memudahkan untuk mengontrol kegiatan yang dilaksanakan. Oleh karena itu dalam penggunaan media bimbingan dan konseling seorang konselor perlu memperhatikan berbagai hal sebagai berikut ini: (a) analisis kebutuhan/permasalahan siswa (b) penentuan tujuan yang akan dicapai (c) analisis situasi dan kondisi sekolah (d) penentuan jenis kegiatan yang akan dilakukan (e) penentuan personel-personel yang akan melaksanakan, (f) perkiraaan biaya yang dimiliki sekolah, (g) mengantisipasi kemungkinan hambatan dalam penggunaan media bimbingan dan konseling, dan (i) waktu dan tempat untuk digunakannya media bimbingan dan konseling.

Seringkali ditemui dalam kegiatan layanan bimbingan dan konseling disekolah, konselor/guru pembimbing menyampaikan materi bimbingan dan konseling kepada siswa hanya dengan mempergunakan cara-cara yang "kuno". Dalam arti bahwa konselor/guru pembimbing hanya sebatas menjelaskan atau memberi ceramah kepada siswa. Keterbatasan metode ini akan membuat dan menggunakan siswa merasa cepat bosan walaupun materi yang diberikan oleh konselor/guru pembimbing sebenarnya sangat menarik.Kegiatan belajar dan kegiatan layanan bimbingan dan konseling di kelas pada dasarnya adalah proses komunikasi. Hal ini menunjukkan bahwa konselor/guru pembimbing sebagai sumber informasi memiliki kebutuhan untuk menyampaikan informasi (materi BK) kepada siswa sebagai penerima informasi. Penyampaian informasi ini dapat melalui cara-cara biasa seperti berbicara kepada siswa, atau melalui perantara yang disebut sebagai media. Penggunaan media BK perlu disadari bahwa berbeda dengan guru bidang studi lain karena sifat tugasnya, maka konselor hendaknya mampu mengalokasikan kegiatan yang ada di dalam kelas dan di luar kelas dengan media yang dapat mendukung kegiatan dimaksud sehingga kegiatan berjalan dengan baik dan dapat mencapai tujuan yang telah ditentukan.

Berdasarkan hasil observasi dalam studi pendahuluan didapatkan bahwa guru BK di SMA/SMK menyatakan belum memahami dan belum mampu untuk menginternalisasi keterampilan merancang media BK kedalam pelaksanaan layanan informasi bimbingan konseling. Hasil wawancara menunjukkan mereka masih terkendala dengan penguasaan teknologi dalam membuat media, selain itu mereka juga tidak paham harus memulai dari mana untuk merancang naskah media yang akan digunakan dalam layanan informasi. Untuk melihat aktifitas mahasiswa dalam merancang media audio visual BK maka pemantauan ini meliputi proses maupun hasil, maka diperlukan asesmen yang digunakan, dimana dalam asesmen yang dilakukan tersebut harus terdapat suatu umpan balik yang efektif, baik efektif dalam arti mengoptimalkan hasil maupun efektif dalam arti membangun tanggungjawab belajar pada diri mahasiswa.oleh karena itu pelatihan ini menggunakan Performance assessment adalah penilaian berdasarkan hasil pengamatan penilai terhadap aktivitas siswa sebagaimana yang terjadi.

Penilaian dilakukan terhadap unjuk kerja, tingkah laku, atau interaksi mahasiswa. Performance assessment digunakan untuk menilai kemampuan mahasiswa melalui penugasan. Penugasan tersebut dirancang khusus untuk menghasilkan respon (lisan atau tulis), menghasilkan karya (produk), atau menunjukkan penerapan pengetahuan. Pelayanan bimbingan dan konseling akan berjalan lebih baik dan menyenangkan apabila disertai dengan pemanfaatan media bimbingan dan konseling yang baik, terarah dan sistematis. Hal ini merupakan manifestasi dan akumulasi kinerja konselor, dan pada gilirannya akan memberikan kesan bahwa konselor bekerja secara profesional dan cakap, efektif, dan efisien, dan tidak gagap teknologi.

\section{Metode}

Sesuai yang telah diuraikan pada bagian pendahuluan maupun bagian analisis situasi, maka khalayak sasaran strategis P2M ini adalah guru BK SMA/SMK di Kota Singaraja yang teridentifikasi belum dapat merancang media audio visual berbasis performance assesment dalam pelaksanaan layanan informasi BK. Guru BK SMA/SMK yang menjadi sasaran pelaksanaan pelatihan ini diperkirakan berjumlah 30 orang yang selain guru BK SMA/SMK juga ada pengawas BK, Ketua MGBK, dan juga mahasiswa jurusan BK FIP Undiksha.

Kegiatan P2M diselenggarakan di ruang seminar FIP Undiksha dengan melibatkan guru-guru bimbingan konseling SMA/SMK di Kota Singaraja Kegiatan P2M ini, selain mengundang guru-guru BK SMA/SMK, juga turut mengundang pihak-pihak terkait seperti ketua LPM Undiksha, kepala sekolah dan pengawas BK kabupaten buleleng, dan juga melibatkan mahasiswa jurusan BK Undiksha. Pelibatan mahasiswa BK dimaksudkan disini karena mereka juga nantinya sebagai calon guru BK di sekolah harus mengetahui permasalahan yang ada dilapangan dan belajar untuk menyelesaikan permasalahaan terebut 
dengan menggunakan pendekatan maupun teknik yang ada dalam bimbingan konseling. Metode yang digunakan untuk mencapai tujuan yang telah dirumuskan dalam P2M ini adalah metode ceramah, diskusi dan juga pelatihan (merancang media audio visual dan refleksi) yang dilaksanakan dalam bentuk seminar dan workshop. Gabungan metode tersebut diharapkan mampu meningkatkan pemahaman guru-guru bimbingan konseling SMA/SMK tentang pentingnya merancang media audio visual dalam pelaksanaan layanan Informasi BK. Gambaran kegiatan yang dilaksanakan adalah sebagai berikut: pertama persiapan meliputi: a) melakukan penjajagan ke Sekolah SMA/SMK di Kota Singaraja, b) melakukan koordinasi dengan LPM Undiksha, pengawas SMK BK kabupaten Buleleng, dan ketua MGBK Kabupaten Buleleng mengenai kegiatan P2M yang akan dilaksanakan, c) Melakukan koordinasi sekaligus memohon izin dengan Wakil Dekan II FIP Undiksha, memohon bantuan untuk kerjasama dalam peminjaman gedung ruang seminar FIP dan fasilitas kegiatan, d) Membuat surat undangan dan menyebarkannya pada undangan yang sudah ditetapkan dalam hal ini sebagai peserta adalah guru BK SMA N 1- 4 Singaraja dan guru SMK N 1-3Singaraja, perwakilan mahasiswa jurusan BK Undiksha, sedangkan undangan dalam kegiatan ini adalah ketua LPM, Pengawas BK di kabupaten Buleleng, ketua MGBK kabupaten Buleleng, e) Menyiapkan narasumber dan moderator, dalam hal ini dilakukan juga koordinasi aagar narasumber menyiapkan materi dan memberikan materi sebelum kegitan dilaksanakan agar dapat diperbanyak untuk diberika pada

peserta dan undangan, dalam kegiatan ini yang menjadi narasumber adalah Ibu Dewi Arum, beliau dalam kegiatan ini mengangkat tema " pentingnya media BK dalam pelaksanaan layanan informasi BK", moderator dalam kegiatan ini adalah Luh Putu Sri Lestari, S.Pd.,M.Pd, f) Menyiapkan materi dan fasilitas kegiatan, dalam hal ini fasilitas yang dimaksud adalah tempat pelaksanaan kegiatan dan juga kelengkapannya seperti LCD, miks, saundsystem dan lain-lain. kegiatan ini berpusat di ruang Seminar FIP Undiksha, setelah tempat kegiatan selanjutnya menyiapkan materi pelatihan (meminta dari narasumber yang ditunjuk), meyiapkan Atk untuk peserta seperti MAP, Bolpoint, kertas, dan lainnya, menyiapkan piagam peserta, konsumsi peserta, dan spanduk kegiatan.

Pelaksanaan. Kegiatan pelatihan ini dilaksanakan dalam dua hari yaitu tanggal 29-30 Juli 2016, namun dalam penentuan hari kegitan tersebut terkendala bnayak hal misalnya kegiatan sekolah yang berbenturan dengan pelaksanaan ujian untuk kelas XII bak itu ujian nasional maupun sekolah setelah itu terbentur juga dengan kegiatan ulangan umum dan akreditasi jurusan BK FIP Undiksha. Kegiatan yang dilaksanakan adalah sebagai berikut: a) Hari ke-1 (Jumat, 29 Juli 2016) Pembukaan (kata sambutan dari ketua LPM dalam hal ini diwakili oleh Pengawas BK kabupaten buleleng,), pemberian ceramah oleh narasumber, dilanjutkan dengan diskusi yang dilakukan oleh peserta dan narasumber, kegiatan diakhir dengan pembacaan hasil diskusi dan perjanjian untuk datang pada kegiatan selanjutnya pada hari berikutnya, b) Hari ke-2 (Sabtu, 30 Juli 2016) kegiatan dibuka pengawas BK dan juga didampingi ketua pelaksana, selanjutnya acara kegitana dilanjutkan dengan pengarahan kembali oleh ketua pelaksana, meminta peserta membentuk kelompok dan melkasanakan pelatihan mulai dari merancang, membuat naskah dan juga mempresentasikannya. kegiatan ditutup dengan pemberian pesan dan kesan mengenai pelaksanaan kegiatan P2M oleh peserta Untuk susunan acara secara lengkap, dapat dilihat pada lampiran.

Rancangan evaluasi. Keberhasilan kegiatan pelatihan ini akan dievaluasi melalui: a) Evaluasi proses: dilihat dari aktifitas peserta mengikuti kegiatan pelatihan, hal ini ditunjukan dengan partisipasi pesrta dalam diskusi (mengajukan atau menjawab pertanyaan), kehadiran peserta dalam kegiatan, kerjasama peserta dalam kegiatan ( mau melaksanakan instruksi yang diberikan oleh narasumber maupun ketua pelaksana). Evaluasi proses dilaksanakan selama kegiatan P2M dilaksanakan, b) Evaluasi hasil/produk: dilihat dari hasil implementasi pelatihan dimana untuk menentukan indikator keberhasilannya digunakan instrumen berupa panduan observasi yang dibuat berdasarkan tiga keterampilan yang ingin dilihat dari mahasiswa, ketiga keterampilan tersebut nantinya akan diukur dengan menggunakan rubrik. Ketiga keterampilan yang dimaksud adalah sebagai berikut: 1) Keterampilan merancang perencanaan membuat media, 2) Keterampilan merancang naskah media BK yang disesuaikan dengan tujuan dan juga sasaran dari pelaksanaan layanan BK, c) Keterampilan membuat media BK sesuai dengan naskah yang telah Dibuat, d) Keterampilan mempresentasikan media BK yang telah dibuat.

\section{Hasil Dan Pembahasan}

Pelaksanaan P2M diawali dengan pra kegiatan yang bertujuan untuk memberikan pemahaman awal kepada guru BK SMA/SMK yang akan ikut pelatihan, pemahan yang diberikan meliputi tujuan pelaksanaan, manfaat pelaksanaan kegiatan, topic kegiatan P2M, hal apa yang akan dilakukan dalam pelatihan, dan terakhir meminta guru membuat pra rancangan media audio visual dalam pelaksanaan layanan informasi bimbingan konseling untuk didiskusikan pada saat kegiatan berlangsung. Pra 
rancangan yang dibuat diberikan ramburambunya, sehingga semua guru memiliki keseragaman sistematika pra rancangan media audio visual yang dibuat. Selama pelaksanaan kegiatan P2M peserta pelatihan terlihat sangat antusias dan aktif baik dalam bertanya maupun menjawab pertanyaan selama diskusi berlangsung. Kegiatan yang dilakukan saat pelaksanaan P2M ada dua yaitu seminar dan workshop, pada saat pelaksanaan seminar guru BK sangat antusias dalam mendengarkan narasumber menjelaskan pentingnya media dalam pelaksanaan layanan informasi BK.

Pada saat kegiatan seminar, diadakan sesi diskusi, semua guru berpatisipasi aktif dalam pelaksanaan kegiatan diskusi, mereka berbagi informasi mengenai kendala yang mereka hadapi saat akan melaksanakan layanan informasi dengan memanfaatkan media, dalam kegiatan seminar itu juga mereka diberiakan trik dan juga kiat-kiat dalam melaksanakan layanan informasi dengan menggunakan media agar layanan yang mereka lakukan dapat efektif dan tepat sasaran. Untuk kegiatan workshop, mereka diminta untuk membuat dua kelompok, dimana kelompok pertama terdiri dari guru SMK, yang tergabung dalamm kelompok ini adalah guru SMK N 1 Singaraja dan guru SMK N 3 Singaraja, sementara kelompok dua adalah kelompok yang terdiri dari guru SMA N 1, 2, dan 4 Singaraja.

kegiatan pertama melatih keterampilan merencanakan pemilihan media dimana dalam aspek ini ada beberapa hal yang dilihat yaitu menentukan tujuan dari pemilihan media BK yang akan dibuat, menentukan sasaran sesuai dengan karakteristik mahasiswa, menentukan karakteristik jenis media yang akan digunakan, menentukan waktu pelaksanaan, menganalisis hambatan dalam pelaksanaan media BK, selanjutnya kegiatan kedua melihat Keterampilan membuat dan menggunakan naskah media BK yang disesuaikan dengan tujuan dan juga sasaran dari pelaksanaan layanan BK, selanjutnya kegiatan ketiga keterampilan membuat media BK sesuai dengan perencanaan dan naskah yang telah dibuat, lalu kegiatan terakhir adalah melatih keterampilan mempresentasikan media BK yang telah dibuat dilihat dari sistematika naskah yang dibuat dan juga kemampuan menyajikan materi serta menanggapi pertanyaan saat presentasi.

Tabel 1 Skor pelaksanaan pelatihan merancang media Audio Visual Guru BK SMA/SMK.

\begin{tabular}{ccccc}
\hline No & Kelompok & Guru & Skor & Katagori \\
\hline 1 & Kelompok 1 & Guru SMK N 1 dan 3 & 80 & Baik \\
\hline 2 & Kelompok 2 & Guru SMA N 1, 2 dan 4 & 83 & Baik \\
\hline
\end{tabular}

Dalam pelaksanaan kegiatan, klompok guru SMA belum dapat menentukan/merumuskan tujuan secara realistik mengapa media BK dibuat, sehingga untuk langkah selanjutnya mereka terhambat seperti menentukan karakteristik dan juga terhambat dalam menentukan waktu pelaksanaan sementara kelompok guru SMK belum mampu membuat naskah media dengan baik karena, naskah media yang mereka buat tidak didasarkan pada perencanaan, malah mereka membuat naskah dengan tujuan bahkan sasaran yang berbeda, mereka hanya melihat pada layanan yang didapat, selain itu baik kelompok guru SMA maupun SMK dalam membuat media mereka langsung mengambil vidio dari youtobe tanpa disesuaikan dengan perencanaan dan naskah yang mereka buat Berdasarkan temuan-temuan observasi tersebut, maka pada sesi evaluasi kegiatan, beberapa rekomendasi yang perlu diperbaiki dalam perencanaan berikutnya yaitu: (1) mengulang kembali konsep materi sehingga kelompok guru SMA maupun SMK mampu memahami pentingnya pelaksanaan metode ini untuk meningkatkan kwalitas media BK audi visual yang dibuat (2) meminta kelompok guru SMA dan SMK untuk lebih serius dan fokus dalam melaksanakan setiap langkah dari kegiatan yang dilakukan, agar kegiatan ini berhasil (3) meminta kelompok guru SMA dan SMK untuk merumuskan tujuan pembuatan media secara realistik sehingga untuk perumusan selanjutnya dapat lebih mudah dilakukan.

Hal positif yang dapat diambil hikmahnya pada proses pelaksanaan di kelompok guru SMA dan SMK ini adalah, mereka terlihat mampu bekerjasama secara baik dalam kelompok dan saling bantu membantu apabila ada diantara mereka yang belum memahami materi, terlihat saat kegiatan mereka memberikan saran dan masukan pada kelompok lain, ada yang bahkan rela melakukan perbaikan atau membenahi vidio yang dianggap kurang menarik, sehingga mereka dapat memperbaiki bersama, mereka selalu mencoba dan berusaha secara serius dan semaksimal mungkin untuk mencapai perubahan yang lebih baik lagi. Demikian hasil observasi pelaksanaan kegiatan kelompok guru SMA/SMK, kemudian hasil kerja kelompok ini dipresentasikan pada peserta lain, dan peserta lain memberikan pendapat terkait produk tesebut, setelah itu salah satu guru BK dalam kelompok itu mempresentasikan rancangan kegiatan tersebut dengan melibatkan mahasiswa. Melihat rancangan yang dihasilkan maka dapat disimpulkan bahwa pelaksanaan P2M berhasil, karena rancangan yang dibuat sesuai dengan indikator dan tagihan yang diminta oleh pelaksana dan juga peserta sudah menunjukan keseriusannya dalam membuat rancangan tersebut. 
Hasil kegiatan ini menemukan bahwa implementasi assessment performance dapat meningkatkan keterampilan mahasiswa membuat media BK. Peningkatan tersebut dapat diamati saat proses kerja kelompok berlangsung, guru BK SMA/SMK sudah mampu menunjukan keterampilan dalam merencanakan pemilihan media yang akan dibuat, keterampilan membuat dan menggunakan naskah media BK yang disesuaikan dengan tujuan dan juga sasaran dari pelaksanaan layanan BK, keterampilan membuat dan menggunakan media BK sesuai dengan perencanaan dan juga naskah yang telah dibuat, dan Keterampilan menggunakan media BK dengan cara mempresentasikan media BK yang telah dibuat. Penyelenggaraan kegiatan ini dilaksanakan dengan menggunakan prinsip performance assesmen dimana penilaian ini menanamkan kebiasaan bekerja dengan baik, seperti bertanggungjawab secara individu maupun kelompok, keterampilan bekerja sama, tekun, memperhatikan keakuratan dan kualitas, jujur, memperhatikan keamanan, dan rapi.

Selain itu performance assesment juga dilihat sebagai suatu sistem untuk menilai proses dan produk serta menilai kualitas penyelesaian produk pada Guru BK SMA/SMK Media bimbingan dan konseling dalam penggunaannya harus relevan dengan tujuan/ kompetensi yang ingin dicapai dan isi layanan bimbingan dan konseling itu sendiri. Hal ini mengandung makna bahwa penggunaan media dalam bimbingan dan konseling harus selalu melihat kepada kompetensi atau tujuan dan bahan atau materi bimbingan dan konseling. Penggunaan media bimbingan dan konseling bukan merupakan fungsi tambahan, tetapi memiliki fungsi tersendiri sebagai sarana bantu untuk mewujudkan situasi bimbingan dan konseling yang lebih efektif. Proses pemilihan media menjadi penting karena kedudukan media yang strategis untuk keberhasilan layanan Bimbingan Konseling.

Alasan pokok pemilihan media dalam Bimbingan Konseling, karena didasari atas konsep bahwa Bimbingan Konseling sebagai sebuah sistem yang di dalamnya terdapat suatu totalitas yang terdiri atas sejumlah komponen yang saling berkaitan untuk mencapai tujuan. Tujuan utama layanan Bimbingan konseling adalah membantu siswa mencapai perkembangan yang optimal. Upaya untuk mewujudkan tujuan tersebut agar mudah tercapai, maka tujuan tersebut diperinci menjadi tugas-tugas perkembangan. Pencapaian tugas perkembangan akan lebih mudah berhasil bila ditunjang oleh media yang sesuai dengan materi, strategi yang digunakan, dan karakteristik siswa. Penggunaan media akan meningkatkan kebermaknaan (meaningful learning) hasil Bimbingan Konseling. Dengan demikian pemilihan media menjadi penting artinya dan ini menjadi alasan teoritis mendasar dalam pemilihan media. Secara teoritis diharapkan menjadi dasar alasan mengapa kita perlu melakukan pemilihan terhadap media, agar memiliki kesesuaian dengan tugas perkembangan siswa, kesesuaian dengan isi, strategi bimbingan dan konseling,dan waktu yang tersedia. Alasan praktis berkaitan dengan pertimbangan pertimbangan dan alasan si pengguna seperti guru BK mengapa menggunakan media dalam bimbingan konseling.

Terdapat beberapa penyebab orang memilih media, menurut Arif Sadiman (1996) ada empat alasan yaitu demonstration, familiarity, clarity dan aktifkan siswa. Di bawah ini diuraikan keempat alasan tersebut. 1) Demonstration. Dalam hal ini media dapat digunakan sebagai alat untuk mendemonstrasikan sebuah konsep, alat, objek, kegunaan, cara mengoperasikan dan lain-lain. Beberapa alasan tersebut sering melandasi pengguna dalam menggunakan media yaitu bertujuan untuk mendemonstrasikan atau memperagakan sesuatu. 2) Familiarity. Pengguna media bimbingan dan konseling memiliki alasan pribadi mengapa ia menggunakan media, yaitu karena sudah terbiasa menggunakan media tersebut, merasa sudah menguasai media tersebut, jika menggunakan media lain belum tentu bisa dan untuk mempelajarinya membutuhkan waktu, tenaga dan biaya, sehingga secara terus menerus ia menggunakan media yang sama. 3) Clarity. Alasan ketiga ini mengapa guru Bimbingan Konseling menggunakan media adalah untuk lebih memperjelas pesan bimbingan dan konseling yang disampaikan dan dapat memberikan penjelasan yang lebih konkrit. Di sinilah banyak pengguna media, memiliki alasan bahwa menggunakan media adalah untuk membuat informasi lebih jelas dan konkrit sesuai kenyataan. 4) Aktifkan siswa/ konseli. Media dapat berbuat lebih dari yang bisa dilakukan oleh guru BK. Salah satu aspek yang harus diupayakan oleh guru BK dalam proses bimbingan konseling adalah siswa / konseli harus berperan secara aktif baik secara fisik, mental, dan emosional.

Berdasarkan pembahasan hasil kegiatan P2M tersebut di atas, sangat penting bagi dosen, untuk berdedikasi membantu meningkatkan keterampilan guru merancang media BK yang salah satunya dapat dilakukan dengan memberikan pelatihan. Pelayanan bimbingan dan konseling dapat berjalan lebih baik dan menyenangkan karena disertai dengan pemanfaatan media bimbingan dan konseling yang baik, terarah dan sistematis. Hal ini nantinya akan berdampak pada manifestasi dan akumulasi kinerja guru BK, yang pada gilirannya akan memberikan kesan bahwa guru BK bekerja secara profesional, cakap, efektif, dan efisien, serta tidak gagap teknologi. Harapannya kegiatan ini mampu dilaksanakan secara continue mengingat saat ini, dosen dituntut bersikap kreatif dan inovatif dengan cara-cara yang tepat dan efektif dalam memberikan sebuah layanan pengabdian pada masyarakat. 


\section{Simpulan Dan Saran}

Berdasarkan hasil dan pembahasan di atas maka dapat disimpulkan sebagai berikut: pertama Kegiatan P2M dapat meningkatkan pemahaman guru BK mengenai media BK khususnya media Audio Visual dalam pelaksanaan layanan informasi Bimbingan Konseling kedua Kegiatan P2M dapat meningkatkan pemahaman dan keterampilan guru BK dalam merancang media BK audio visual dalam pelaksanaan layanan informasi BK. Ketiga Antusiasme Guru BK sebagai peserta sangat baik dalam mengikuti kegiatan pelatihan dari awal kegiatan hingga akhir.

Berdarkan hasil kesimpulan, maka saran yang dapat diajukan adalah sebagai berikut: Bagi guru BK yang menjadi peserta kegiatan ini, diharapkan agar dapat mengaplikasikan pengalaman yang telah didapat dalam kegiatan P2M di sekolah masing-masing dan setelah ini dapat menyempurnakan rancangan media BK Audio Visual sesuai dengan kebutuhan dan permasalahan siswa yang ada disekolah Bagi kepala sekolah, Pengawas BK, ketua MGBK agar terus memperhatikan peningkatan profesionalisme guru BK melalui pemberian kesempatan mereka untuk mengikuti pelatihan-pelatihan guna menunjang profesionalisme guru BK. Bagi para pelaksana kegiatan P2M, model seminar dan workshop seperti ini perlu dilakukan juga terhadap guru BK SMA/SMK di wilayah Kabupaten Buleleng dan tentunya diwilayah propinsi Bali sehingga sehingga hal ini dapat memberikan pemahaman yang sama pada guru BK dan tentunya dengan pelkasanaan layanan informasi yang menyenangkan permasalahan siswa dapat dibantu untuk diselesaikan.

\section{Daftar Pustaka}

Airasian,Peter.W. 1991. Classroom Assessment. USA: McGraw-Hill.

Hutabarat, O. R. 2004. Model-model Penilaian Berbasis Kompetensi PAK. Bandung: Bina Media Informasi.

Iryanti, Puji. 2004. Penilaian Unjuk Kerja. Yogyakarta: Depdiknas.

Mahmudah, S.2000. Penerapan Penilaian Kinerja Siswa (performance Assessment) pada Pembelajaran Sub Konsep Jaringan Hewan. Bandung:UPI

Majid, A. 2006. Perencanaan Pembelajaran Mengembangkan Standar Kompetensi Guru. Bandung: Remaja Rosdakarya.

Popham, W. 1995. Classroom Assessment. Boston: Allyn and Bacon. Setyono, Budi.2005. Penilaian Otentik dalam Kurikulum Berbasis Kompetensi (dalam jurnal pengembangan pendidikan). Lembaga Pembinaan dan Pengembangan Pendidikan (LP3) Universitas Jember.

Sutrisno, Hadi. 2006. Metodologi Research. Yogyakarta: PT Andi Ofset.

Stiggin, R.J.1994. Student-Centered Classroom Assessment. New York: Mac Millan College Publishing Company.

Zainul, Asmawi. 2001. Alternative Assessment. Jakarta: Universitas Terbuka. 